\title{
Proboscis monkeys and their swamp forests in Sarawak
}

\author{
Elizabeth L. Bennett
}

Proboscis monkeys, endemic to the island of Borneo, are declining in Sarawak. Their mangrove and peat swamp forest habitats are being degraded or destroyed and people continue to hunt them despite their protected status. Surveys between 1984 and 1986 established the status of this monkey and its habitats in this Malaysian state. The author who participated in the surveys, receiving some financial support from the Oryx $100 \%$ Fund, discusses the results and makes recommendations for future conservation action.

Proboscis monkeys Nasalis larvatus are endemic to Borneo in South-East Asia (Figure 1) and are largely confined to mangrove, riverine and peat swamp forests of the coastal lowlands (Davis, 1962; Payne et al., 1985). Populations are occasionally found much further inland next to major rivers (Jeffrey, 1982; Chivers et al., 1986; MacKinnon, 1986; C.W. Marsh, pers. comm.), and there are even less frequent reports of apparently nomadic animals passing briefly through hill forest areas in the Bornean interior (Bennett, 1986). They are not resident in the extensive areas of lowland and hill dipterocarp forest throughout most of inland Borneo.

Until recently, no systematic surveys of the species had been conducted, and there were no reliable data on its status. More was known about the animals in the Malaysian state of Sarawak than elsewhere in their range (e.g. Salter and MacKenzie, 1985). Indications were that numbers had declined sharply in recent years, but estimates were based on scanty data from few areas. It is not possible to extrapolate these data to estimate numbers in other areas because the occurrence and abundance of proboscis monkeys varies enormously in different patches of swamp forest, even if they appear superficially similar.

Between 1984 and 1986 a series of surveys of the proboscis monkey and its habitats was conducted Proboscis monkeys in Sarawak in Sarawak in order to determine their status, to predict future trends, and to make recommendations to ensure their survival in this part of Borneo.

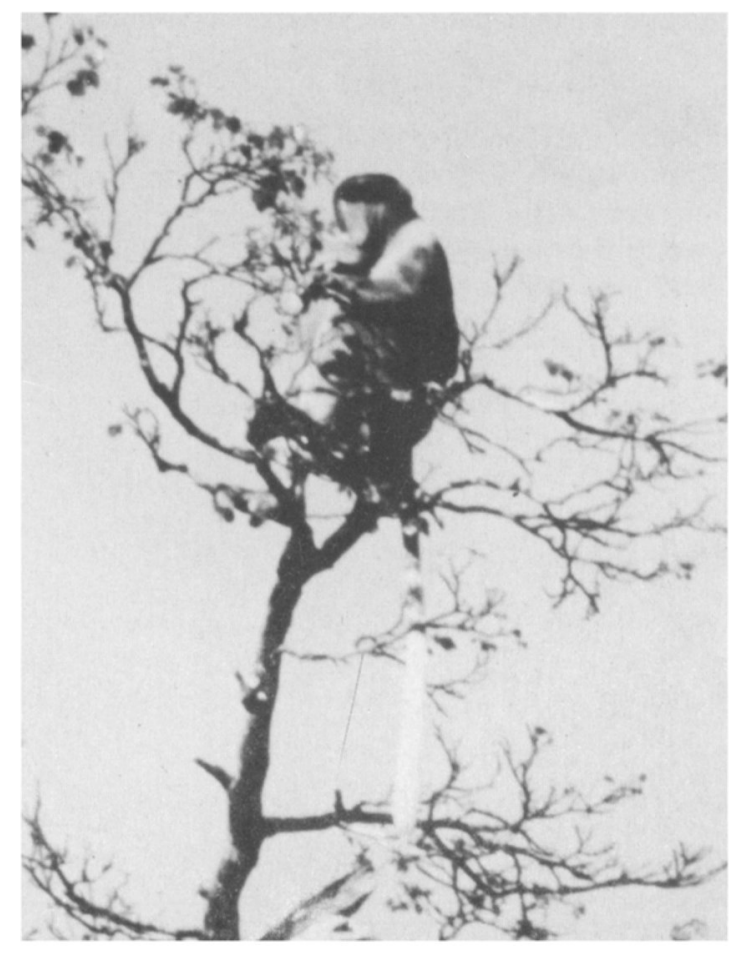

Male proboscis monkey feeding (E.L. Bennett).

69 


\section{The surveys}

Two types of survey were conducted. Firstly the availability of possible proboscis monkey habitat was assessed by flying a small helicopter or light aircraft over the peat swamp and mangrove forests in the coastal plain. Within these potential habitats, areas that were large enough to contain potentially viable populations of proboscis monkeys were identified. Since proboscis monkeys have home ranges of at least $9 \mathrm{sq} \mathrm{km}$ (Bennett, 1986), these areas had to contain an absolute minimum of $10 \mathrm{sq} \mathrm{km}$ of relatively intact forest. Once they had been identified from the air, each was surveyed by boat to discover whether proboscis monkeys occurred there, and if so the approximate size of each population. Proboscis monkeys invariably sleep next to rivers every night (Bennett, 1986). It is possible, therefore, to establish their presence in an area and to obtain a rough index of abundance by going along the rivers immediately before dusk and after dawn, and counting the number of proboscis monkeys encountered (both individuals and groups) (for details of methods see Bennett, 1986).

\section{Status of the habitats}

Peat swamp forests are widespread in Sarawak, occupying approximately $14,736 \mathrm{sq} \mathrm{km}$ or 11.9 per cent of the land area. They were, however, among the first areas to be logged. Mechanical

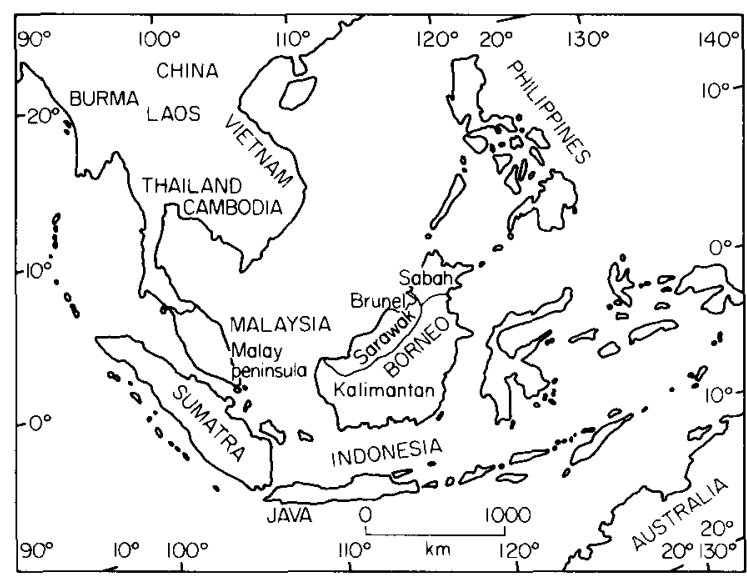

Figure 1. South-East Asia, showing the major geographical 70 logging started in 1947 and, for many years after that, peat swamp forests were the State's major source of timber. By 1979, almost all peat swamp forests had been licensed for timber extraction (Lee, 1981), and by the year 2000 they will all have been logged (Chan et al., 1985).

Logging of peat swamps is generally less damaging to the soil than logging in dipterocarp forests, largely because logs are removed on railway tracks rather than roads. This requires a narrower path through the forest, and also causes less soil compaction. Regeneration is slow, however (Chan et al., 1985). Mixed species stands, presumably the best for wildlife, regenerate better than pure stands. Regenerated forest will not be as productive as the first cut (Forest Department, pers. comm., in Chan et al., 1985), and the longterm effect of logging on wildlife in peat swamps is totally unstudied. In some areas of logged peat swamp forest, proboscis monkeys survive at relatively high densities (e.g., in Tanjong Puting National Park, Kalimantan). It is not known if this is a short-term phenomenon, or dependent on proximity to a primary forest 'reservoir'.

Another problem is that, in Sarawak, some peat swamp forests are subjected to silvicultural treatment following logging. This involves poisoning non-timber trees (many of which are important food sources for mammals and birds) with the aim of increasing timber yield on the second cut. This is likely to render the forest uninhabitable for many species of wildlife, including the proboscis monkey.

However, it is difficult and expensive to convert forest growing on deep peat to agriculture (Anon., 1976). Where the peat is shallower, swamp forest has been converted to rice and pineapple fields, and coconut and sago plantations. So far this has only taken place on a relatively small scale, but with the advent of comprehensive rural development schemes in certain areas, peat swamp is likely to be converted to agriculture on a wider scale in the near future (Chan et al., 1985).

Mangroves are more limited in extent than peat swamps, occupying only $738 \mathrm{sq} \mathrm{km}$ or 1.4 per cent of Sarawak's land area. Mangroves have been used in many traditional ways for a long time. The main products extracted have been Oryx Vol 22 No 2, April 1988 


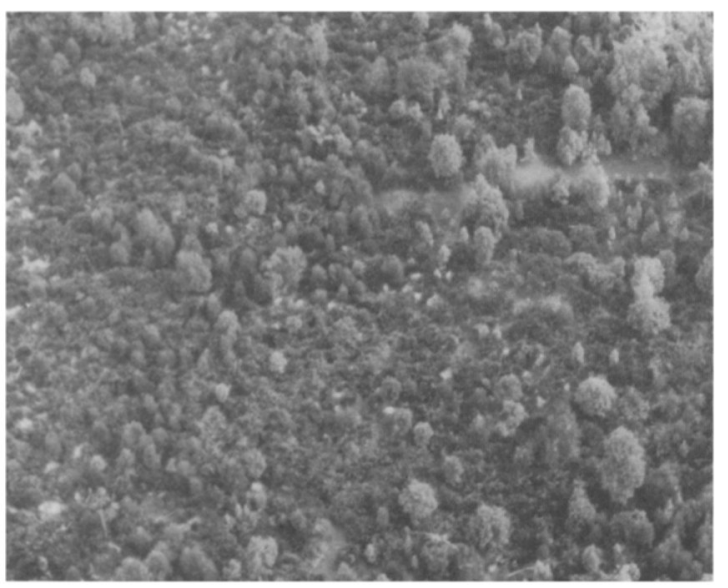

Old logged mangrove from the air, Rajang Delta, Sarawak (E.L. Bennett).

poles for construction, firewood and the production of charcoal: fronds of the nipa palm for making thatch; sugar from nipa flower stems for producing alcohol; and tannin from the sap of mangrove trees for waterproofing fishing nets (Chai, 1982; Gervis, 1986). In addition, the mangroves support major inshore and offshore fisheries: many species of fish and prawns are dependent on food and shelter from the mangroves for all or part of their life-cycle (Whitten et al., 1984; Chan et al., 1985; Kam and Leong, 1985; Gervis, 1986). All of these uses, if carefully controlled, are fully compatible with the continued existence of the mangrove forests and their wildlife.

Since 1969, however, commercial exploitation of mangroves has proceeded at a great rate, mainly to provide woodchips for export to Japan, and also cordwood for export to Taiwan (Chai, 1982). The minimum legal felling girth for timber extraction in mangroves is $23 \mathrm{~cm}$, but up to 90 per cent of all trees are larger than this, so areas are virtually clear felled (Chai and Lai, 1980). As a result, approximately $20 \mathrm{sq} \mathrm{km}$ are lost each year to woodchip production (Gervis, 1986). Regeneration is negligible in heavily logged areas because few mature trees are left to supply seeds and suitable environmental conditions. (Chai and Lai, 1980; Chan, 1984). The Forest Department has replanted some areas and conducted experiments in improving regeneration but, so far, with limited success (Chai and Lai, 1980).
Some of the few remaining patches of relatively intact mangroves are under threat from commercial aquaculture schemes. These involve total clearance of an intact area of mangrove and the building of ponds in which fish or prawns are reared. Such ponds have a high failure rate due to acidic soil conditions (Ong, 1982; Kam and Leong, 1985). Moreover, the natural fisheries productivity of mangroves is unlikely to be matched by that of prawn culture within the area (Ong, 1982). In Sumatra, for example, a coastal fishpond produces $287 \mathrm{~kg}$ of fish/ha/year, but a loss of 1 ha of mangrove to a pond leads to a net loss of $480 \mathrm{~kg}$ of offshore fish and shrimp/ha/year (Whitten et al., 1984).

The overall effect of these changes is that the area of habitat for the proboscis monkeys in Sarawak has been depleted severely in recent years. Remaining areas large enough to contain potentially viable populations are listed below (see also Figure 2).

Samunsam Wildlife Sanctuary and environs, a totally protected area of $60.9 \mathrm{sq} \mathrm{km}$ and surrounding forest. The area comprises a mixture of mangrove, riverine, heath and lowland forests.

The Sarawak Mangroves Forest Reserve, a mangrove area exploited for traditional products and commercial poles. If carefully controlled, these can continue to be collected on a sustained-yield basis without unduly harming the wildlife. Clearfelling for an aquaculture scheme threatens 12 per cent of the 131-sq-km forest reserve.

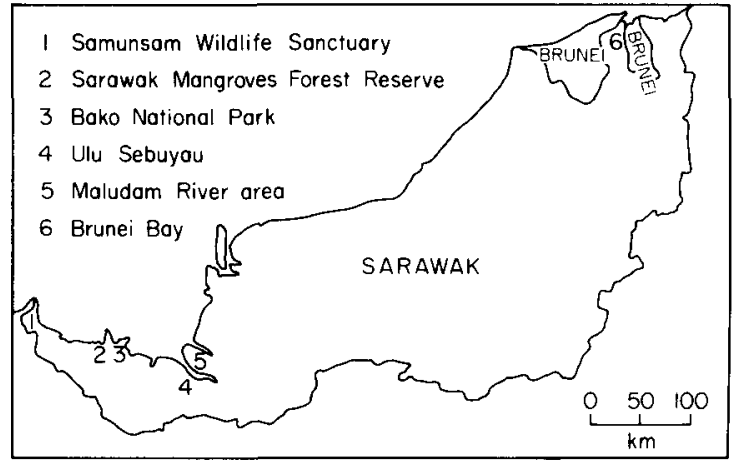

Figure 2. Sarawak, showing the main centres of population of the proboscis monkeys. 


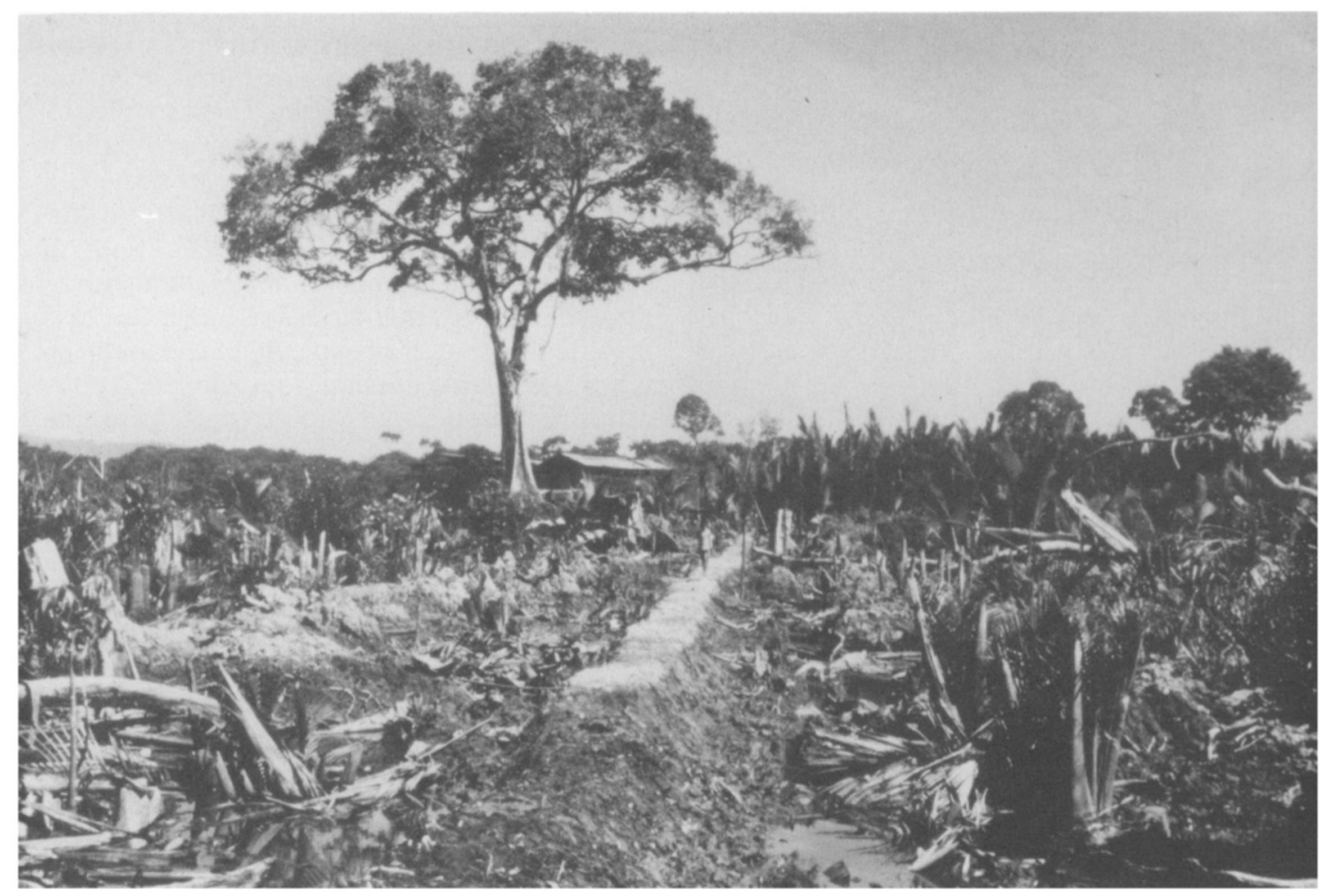

Clearance of mangrove for prawn ponds (E.L. Bennett).

Bako National Park and environs, a totally protected 24-sq-km area of mangrove, heath and lowland forests.

The Maludam River area, a peat swamp forest of $434 \mathrm{sq} \mathrm{km}$. This is being selectively logged on a 25-year cycle, and non-timber trees are being poisoned after logging.

The mangroves of Brunei Bay, a large area of mangroves, traversing the boundary between Sarawak and Brunei Darussalam. The sections in Sarawak are under threat from commercial and coconut schemes.

Other patches of intact habitat do remain, but they are probably too small to contain viable populations of proboscis monkeys.

\section{Status of the proboscis monkeys}

The major cause of the recent decline in the number of proboscis monkeys in Sarawak has undoubtedly been habitat destruction. An additional problem in some of the remaining areas 72 had been hunting. In the inland areas of Sarawak rural people are strongly dependent on hunting wild meat for much of their protein supply (Caldecott, 1986). In mangrove areas, however, hunting is predominantly for sport, by townsfolk who enter the area in speedboats. The proboscis monkeys' habit of sleeping next to rivers makes them extremely vulnerable to hunters, and this has reduced numbers considerably in some areas. Such hunting is illegal because the species is totally protected by law.

The only areas with sizeable populations of proboscis monkeys remaining in Sarawak are Samunsam (approximately 160 animals), Maludam (maybe up to 200 animals), Sarawak Mangroves area (population unknown but certainly not more than 200 animals; this could increase if hunting were stopped) and Bako National Park (106-144 animals: Salter and MacKenzie, 1985). The population in Brunei Bay is divided between Sarawak and Brunei, and it is impossible to determine the number living exclusively in Sarawak. There are probably no more

Oryx Vol 22 No 2, April 1988 
than 300 animals in the whole Brunei Bay area, and the Sarawak population is almost certainly less than half of the total. In about 1979, there was a population of up to 200 individuals in Ulu Sebuyau (Figure 2), but they are likely to have been subjected to hunting pressure and their current status is unknown (Banggan Empulu, pers. comm.; Jawa bin Bakar, pers. comm.). There are undoubtedly other pockets of population elsewhere, but they are certainly extremely small and unlikely to be viable.

These figures are highly provisional and must be treated with extreme caution, but it seems likely that the total population of proboscis monkeys in Sarawak might be as low as 1000 individuals. This is bound to decrease unless action is taken. The only populations that are protected are those in Samunsam Wildlife Sanctuary and Bako National Park. The survival of neither of these is fully assured: both are too small at present to guarantee that they could contain a viable population if isolated (Bennett, 1986). The overall conclusion must be that proboscis monkeys are endangered in Sarawak, and that immediate steps need to be taken to guarantee their survival.

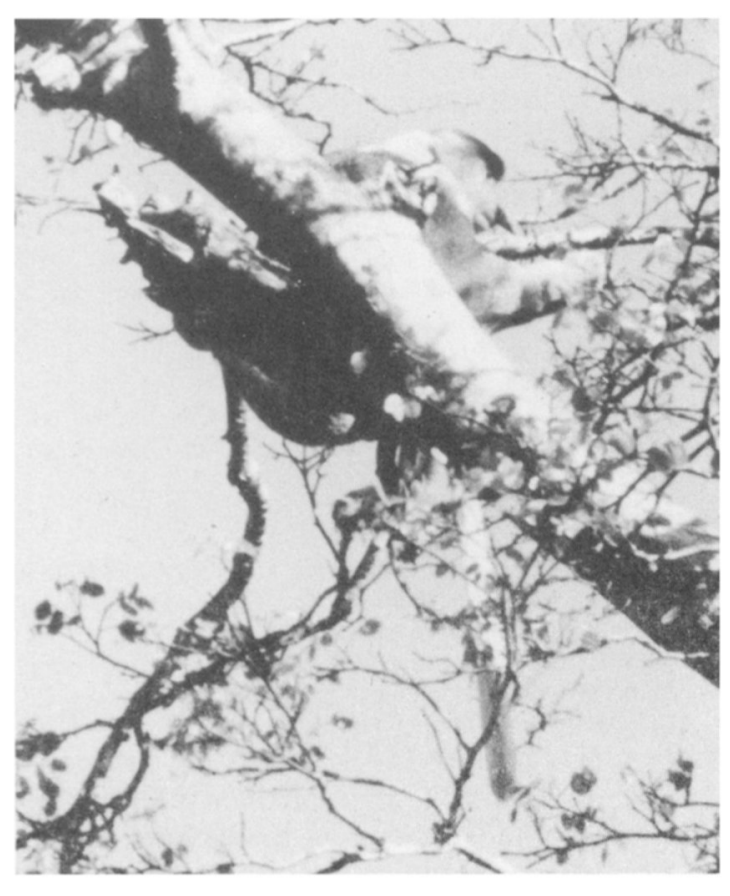

Male proboscis monkey (E.L. Bennett).

Proboscis monkeys in Sarawak

\section{Conservation implications}

Three main spheres of action are required to ensure the survival of proboscis monkeys in Sarawak: protection of more areas of habitat; enforcement of anti-hunting laws; and increasing public awareness about the value of the animals and their habitats.

In terms of protected areas, the Sarawak Forest Department established Samunsam Wildlife Sanctuary in 1979 specifically to protect its proboscis monkeys. The sanctuary is currently not large enough to protect its population effectively (Bennett, 1986), but plans to extend it are already under way (Anon., 1985). The protection of totally new areas is inevitably difficult because of the large number of other pressures on the land: the coastal lowlands are the most heavily populated areas of the state. Centres of population are generally around river mouths and deltas, the main habitats of the proboscis monkeys. In mangrove sites in particular, protecting land exclusively for the preservation of rare animal species is unlikely to prevail against other demands on the area. The only feasible approach is to protect mangrove areas for integrated use by local communities and wildlife alike. Essentially, this means areas would be protected against outsiders logging the area or destroying the mangroves for other schemes. The local residents could continue to fish and extract poles and nipa fronds from certain zones, and protection from outside schemes would guarantee that they could do so. Simultaneously, the habitat would be protected for wildlife. The high natural productivity of mangroves means that they are ideally suited for such integrated use schemes.

Preliminary plans are being made to protect at least one area of mangrove in this way (the Sarawak Mangroves Forest Reserve seems the ideal candidate), and also to protect at least one area of peat swamp forest.

The National Parks and Wildlife Office of the Sarawak Forest Department is also increasing anti-hunting patrols in certain key areas. In addition, it is initiating a major campaign on conservation education. Education on proboscis monkeys, their habitats and the laws protecting them will be integrated into this. 
These measures are set against a background of considerable interest in wildlife and its conservation, both amongst members of the public (particularly in rural areas) and members of government. In 1984, for example, a Special Select Committee of the Sarawak Legislative Assembly was set up. Its brief was specifically to look into the problems of declining wildlife in the state. Such interest means that there is at least a good chance of the remaining populations of proboscis monkeys in Sarawak being protected.

As a final note, the status of proboscis monkeys in other parts of their range is largely unknown. Two-thirds of their range lies in Kalimantan (Indonesian Borneo). Considerable areas of swamp forest remain there, but no systematic surveys of proboscis monkeys have ever been conducted. As outlined above, it is impossible to estimate abundance by extrapolating from densities in a few known areas. Surveys are urgently needed to determine their status and the action needed to conserve the animals in these other parts of their range.

\section{Acknowledgments}

The project in Sarawak is being conducted jointly by Sarawak Forest Department, World Wildlife Fund Malaysia, and the New York Zoological Society. I am extremely grateful to all of the people in these organizations who have given so generously of their time, support and expertise. In particular, I would like to thank Mr Leo Chai (Director of Forests), Dr Paul Chai and Mr Philip Ngau Jalong (successive heads of the National Parks and Wildlife Office of the Forest Department) and $\mathrm{Mr}$ Francis Gombek (Wildlife Officer) for their collaboration and support. All aerial surveys were conducted courtesy of the Royal Malaysian Air Force, whose role in this project has been invaluable. Particular thanks are due to Bric. Jen. (U) Huang Chew Siong, Lt. Kol. (U) Sharkawi Hj. Hasbie, Mej. (U) Benjamin Yong and Mej. Anwar Basha Khan. Drs Julian Caldecott, Michael Kavanagh and Thomas Struhsaker have given invaluable advice and support throughout. The author's financial support comes from World Wildlife Fund Malaysia and the New York Zoological Society, with additional contributions from the Fauna and Flora Preservation Society and the Primate Society of Great Britain. Dr Michael Kavanagh and Mr Philip Ngau Jalong also kindly commented on a draft of this manuscript.

I would like to dedicate this article to the memory of Moray J. Lewis. His tragic death during its preparation will be a loss to wildlife research and conservation in Sarawak.

\section{References}

Anon. 1976. Peat and podzolic soils and their potential for agriculture in Indonesia. Soil Res. Inst. Bogor Bull. 3, $1-195$
Anon. 1985. Proposal to Extend Samunsam Wildlife Sanctuary in the First Division. National Parks and Wildlife Office, Forest Dept., Kuching, Sarawak.

Bennett, E.L. Proboscis Monkeys in Sarawak: Their Ecology, Status, Conservation and Management. World Wildlife Fund Malaysia, Kuala Lumpur and New York Zoological Society, New York.

Caldecott, J.O. 1986. Hunting and Wildlife Management in Sarawak. World Wildlite Fund Malaysia, Kuala Lumpur.

Chai, P.P.K. 1982. Ecological studies of mangrove forest in Malaysia. PhD thesis, Universiti Malaya, Kuala Lumpur.

Chai, P.P.K. and Lai, K.K. 1980. Management and utilization of the mangrove forests of Sarawak. Paper delivered at the ASEAN Symposium of Mangrove Environment: Research and Management, Kuala Lumpur, 25-29 August 1980.

Chan, H.T. 1984. Coastal and riverbank erosion of mangroves in Peninsular Malaysia. Paper presented at the NARU Conference and Workshop in Coasts and Tidal Wetlands of the Australian Monsoon Region, November 1984, Darwin, Australia.

Chan, L., Kavanagh, M., Cranbrook, Earl of, Langub, J. and Wells, D.R. 1985. Proposals for a Conservation Strategy for Sarawak. World Wildlife Fund Malaysia, Kuala Lumpur/State Planning Unit of Sarawak, Kuching.

Chivers, D.J., Ridgeway, R., Djatnika, N. and Burton, K. 1986. Project Barito Ulu: reconnaissance report. Subdepartment of Veterinary Anatomy, University of Cambridge.

Davis, D.D. 1962. Mammals of the lowland rain-forests of North Borneo. Bull. Nat. Mus. Singapore, 31, 1-129.

Gervis, M. 1986. The status of and recommendations for the protection and use of mangrove areas in Sarawak. Report to the Adhoc Subcommittee on Fisheries, Reptiles and Amphibians of the DUN Select Committee on the Conservation of Flora and Fauna in Sarawak.

Jeffrey, S.M. 1982. Threats to the proboscis monkey. Oryx, 16, 337-339.

Kam, S.P. and Leong, Y.K. 1985. Mangrove and corals--an evaluation for the Nation Coastal Erosion Study. Universiti Sains Malaysia, Pulau Pinang.

Lee, H.S. 1981. Silvicultural management options in the mixed dipterocarp forests of Sarawak. Master's thesis, Australian National University.

MacKinnon, K.S. 1986. The conservation status of Indonesian primates. In Current Issues in Primate Conservation leds M.F. Stevenson, D.J. Chivers and J.C. Ingram), pp. 30-35. Primate Society of Great Britain, Bristol.

Ong, J.E. 1982. Mangroves and aquaculture in Malaysia. Ambio, 11, 252-257.

Payne, J., Francis, C.M. and Phillips, K. 1985. A Field Guide to the Mammals of Bomeo. The Sabah Society/World Wildlife Fund Malaysia, Kuala Lumpur.

Salter, R.E. and MacKenzie, N.A. 1985. Conservation status of the proboscis monkeys in Sarawak. Biol. Conserv. 33, $119-132$

Whitten, A.J., Damanik, S.E., Anwar, J. and Hisyam, N. 1984. The Ecology of Sumatra. Gadjah Mudah University Press, Yogyakarta, Indonesia.

Elizabeth L. Bennett, WWF Malaysia, 7 Jalan Ridgeway, Kuching, Sarawak. 